\title{
The Mediating Role of Entrepreneurial Orientation on the Knowledge Creation-Firm Performance Nexus: Evidence from Indonesian IT Companies
}

\author{
Desman Hidayat $^{1,{ }^{*}}$, Edi Abdurachman ${ }^{2}$, Elidjen $^{2}$, Yanthi Hutagaol ${ }^{3}$ \\ ${ }^{1}$ BINUS Entrepreneurship Center, Management Department, Bina Nusantara University, Jakarta, Indonesia 11480 \\ ${ }^{2}$ Management Department, BINUS Business School Doctor of Research in Management, Bina Nusantara University, Jakarta, Indonesia \\ 11480
}

${ }^{3}$ International Accounting \& Finance Program, Accounting Department, Faculty of Economics \& Communication, Bina Nusantara University, Jakarta, Indonesia 11480

\begin{tabular}{l} 
A R T I C L E I N F O \\
\hline Article history: \\
Received: 16 September, 2020 \\
Accepted: 21 January, 2021 \\
Online: 12 February, 2021
\end{tabular}

Keywords:

Knowledge Creation

Entrepreneurial Orientation

Firm Performance

\begin{abstract}
A B S T R A C T
Disruptive innovation has created fast changes in the business environment and competition among companies, especially on information technology companies. Knowledge creation and entrepreneurial orientation are two variables that can improve firm performance. There is still limited study on how knowledge creation and entrepreneurial orientation both affects firm performance. This study aims to discuss how to effectively apply knowledge creation and entrepreneurial orientation to develop firm performance. A questionnaire has been conducted to 55 medium-large IT companies in Jakarta, Indonesia, and analyzed using structural equation modeling (SEM). The result showed that knowledge creation did not directly affect firm performance but indirectly affected entrepreneurial orientation. Knowledge creation also had a positive and significant effect on entrepreneurial orientation, and so does entrepreneurial orientation towards firm performance. Therefore, IT companies should consider both variables to improve their performance. Future studies may consider using qualitative or mixed-method approaches, conducting research for small IT companies and in other countries.
\end{abstract}

\section{Introduction}

The world is changing fast with the innovation that happens in the world. Disruptive innovation, where a new market disrupts and replaces the old market, shows how quickly the world is changing [1]. This situation raises the competition among companies as well $[2]$.

Disruptive innovation heavily impacts the information technology (IT) sector. As the largest economy in South East Asia, Indonesia has many growing industries, especially in the digital sector [3]. Nevertheless, IT companies need to prepare themselves for disruption and the competitive environment to survive.

According to dynamic capabilities theory, companies need to explore their knowledge assets to face rapid technological change [4]. Knowledge is an essential part of IT companies that focus

\footnotetext{
*Corresponding Author: Desman Hidayat, Email: d4906@binus.ac.id
}

more on intangible assets to compete. Knowledge creation is a way to create value for IT companies.

Technology advancement that changes rapidly can help companies find new opportunities to improve their performance [5]. One of the sectors that are affected by these changes is the IT sector. So, IT companies need to find a way to seek opportunities within this condition. Entrepreneurial orientation can be one way where they will be able to survive the competition and to increase their performance [6].

Although there are a lot of previous studies talking about how knowledge creation is related with entrepreneurial orientation [7, 8] and how each of those variables are related with firm performance [9], [10], but there is still limited study on how knowledge creation and entrepreneurial orientation both affects firm performance. It is also interesting to see how the variables will be related in IT sector that relies on intangible assets, such as knowledge. These explanations show the novelty of this study. 
This study aims to enrich the literature by investigating the interaction between knowledge creation, entrepreneurial orientation, and firm performance. Overall, this study makes two contributions: (1) It expands the understanding of the knowledge creation-firm performance relationship in IT companies, and (2) It explores how entrepreneurial orientation can be related to knowledge creation and firm performance.

\section{Literature Review}

\subsection{Firm Performance}

Firm performance is a variable that is often used to measure how good companies run. Researches often use firm performance as a dependent variable [11]. This study used firm performance to measure how good IT companies manage their businesses.

Firm performance is derived from the organizational effectiveness theory [12]. The performance of a company can show the effectiveness of that organization [13]. It takes more than just the financial factor to measure performance [12].

In this study, the firm performance was measured using financial and non-financial performance. It used five indicators: revenue, ROI, employees, products, and development [14, 15]. Financial performance was measured by using revenue and ROI, while non-financial performance was measured using employees, products, and development.

\subsection{Knowledge Creation}

Knowledge creation is an activity or process of developing new knowledge by sharing and combining tacit and explicit knowledge [16]. It enables firms to improve efficiency and create value [17]. Knowledge creation needs participation from individual members of an organization to be effective [18].

Knowledge-based view of the firm is the most common foundation used to define knowledge creation theory [19]. This view argued that firms' significant resources are mainly intangible and dynamic, such as knowledge [20]. This view is derived from dynamic capabilities.

Socialization, Externalization, Combination, and Internalization (SECI) are indicators to measure knowledge creation [18]. These indicators are representing the interaction between tacit and explicit knowledge [19]. This study used SECI as indicators to measure knowledge creation.

\subsection{Entrepreneurial Orientation}

Entrepreneurial orientation is one of the most researched topics in entrepreneurship literature [21]. It is the processes, practices, philosophy, and decision-making activities that help companies innovate [22]. Companies with the right entrepreneurial orientation continuously try to find new opportunities and strengthen their competitive positions [8].

The foundation of entrepreneurial orientation was based on entrepreneurship theory itself, where the main point of entrepreneurship is to understand how companies can seek and exploit opportunities [23]. Opportunities do not have to be related to something new, but they can focus on optimizing the existing framework. To discover the opportunities, companies must possess prior information related to the opportunities and cognitive properties to value them.
Five indicators are commonly used to measure entrepreneurial orientation. Those indicators are autonomy, innovativeness, risktaking, proactiveness, and competitive aggressiveness [6]. The earlier concept of entrepreneurial orientation used three aspects: innovativeness, proactiveness, and risk-taking [24], but now it has been improved by adding the other two indicators. This study used the five indicators mention above to measure entrepreneurial orientation.

\subsection{Hypothesis Development}

Knowledge is one of the critical intangible resources that can help companies develop their performance [9, 25]. A lot of previous studies discuss how vital knowledge creation in relationship with performance [19]. High-tech companies need to have adequate knowledge resources in order to remain competitive [26]. Hence the hypothesis:

$\mathrm{H} 1$ : There is a positive effect of knowledge creation towards firm performance.

Entrepreneurial orientation has been known to have a positive association with firm performance [8,9]. It has been tested in different contexts and countries [27]. This statement is also argued to be true for technological companies [28]. Therefore, hypothesis two is predicted as below.

$\mathrm{H} 2$ : There is a positive effect of entrepreneurial orientation towards firm performance.

Knowledge creation and entrepreneurial orientation are often researched together. Previous studies showed that both variables are related $[7,8]$. IT companies need to pay attention to both variables to maximize their performance. Therefore, hypothesis three states:

H3: There is a positive effect of knowledge creation towards entrepreneurial orientation.

Even though most of the previous research discussed how knowledge creation and entrepreneurial orientation separately affect firm performance, some studies talked about how they can simultaneously affect firm performance by having entrepreneurial orientation as the mediating variable [29]. This study argued that innovativeness and competitive aggressiveness as part of entrepreneurial orientation play the mediator between knowledge and performance. Hence the hypothesis:

H4: There is a positive indirect effect of knowledge creation towards firm performance mediated by entrepreneurial orientation.

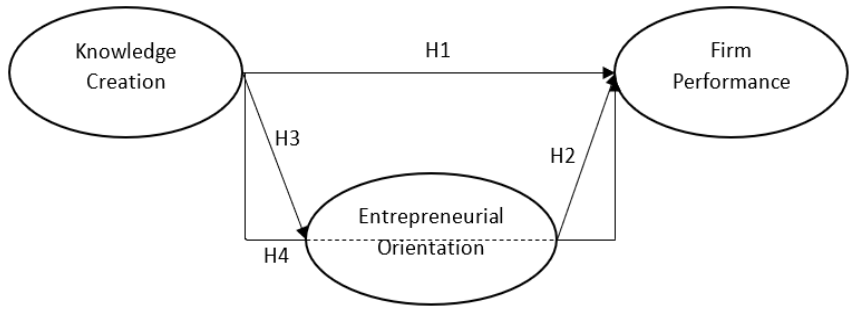

Figure 1: Research Model

\section{Research Methodology}

This study was conducted using an online survey with quantitative analysis. The unit analysis of this study is medium- 
large IT companies in Jakarta. Indonesian Micro, Small, and Medium Enterprise Regulation No.20 (2008) defined medium enterprises as companies with 2.5-50 billion IDR revenues per year or 178-3.5 million USD and large enterprises as companies that have $>50$ billion IDR revenues per year or $>3.5$ million USD. According to 2016 Economic Census by Statistics Indonesia, the population of medium-large IT companies in Jakarta, the capital of Indonesia, is 303 companies [30].

This study used probability sampling design with simple random sampling. The samples for this study were 55 companies. The minimum sample size was 33 data, calculated using two arrows pointing at a construct, 5\% significance level, and minimum R Square 0.25 [31]. Therefore, the samples are sufficient for this study. The survey was conducted for three months, from August to November 2020. The unit of observation in this study was a managerial level employee. Only one employee per company participated in this study.

Based on the companies' established period, most of the respondents $(42 \%)$ were companies that have already been established for at least twenty years, and the smallest frequency came from new companies that have only been established for less than five years (7\%). This data shows that many medium and large IT firms in Jakarta took a long time to develop their business into a medium-large company. Table 1 shows the details of the company establishment period.

Table 1: Companies’ Established Period

\begin{tabular}{|l|l|l|}
\hline Established Period & Frequency & Percentage \\
\hline$<5$ years & 4 & $7 \%$ \\
\hline $5-9$ years & 11 & $20 \%$ \\
\hline $10-14$ years & 9 & $16 \%$ \\
\hline $15-19$ years & 8 & $15 \%$ \\
\hline$>=20$ years & 23 & $42 \%$ \\
\hline TOTAL & 55 & $100 \%$ \\
\hline
\end{tabular}

Most of the company respondents have 11-50 employees (40\%). Only one respondent has less than ten employees, while

Table 3: Validity \& Reliability Test Result

\begin{tabular}{|c|c|c|c|c|c|c|c|}
\hline Variables & Indicators & Items & Instrument & $\begin{array}{c}\text { Outer } \\
\text { Loading }\end{array}$ & $\begin{array}{l}\text { Cronbach's } \\
\text { Alpha }\end{array}$ & CR & AVE \\
\hline \multirow{8}{*}{ EO } & \multirow[t]{2}{*}{ Autonomy } & EO11 & $\begin{array}{c}\text { Our company gives freedom to employees or team } \\
\text { to express their business concept and vision, and } \\
\text { oversees them until finish }\end{array}$ & 0.783 & \multirow{8}{*}{0.892} & \multirow{8}{*}{0.913} & \multirow{8}{*}{0.569} \\
\hline & & EO12 & $\begin{array}{l}\text { Our company has the self-directed ability and } \\
\text { willingness to seek for opportunities }\end{array}$ & 0.809 & & & \\
\hline & \multirow[b]{2}{*}{ Innovativeness } & $\mathrm{EO} 21$ & Our company supports employees' creativity & 0.771 & & & \\
\hline & & $\mathrm{EO} 22$ & $\begin{array}{l}\text { Our company has a lot of new marketable } \\
\text { products/services within the last five years }\end{array}$ & 0.723 & & & \\
\hline & \multirow[t]{2}{*}{ Proactiveness } & EO41 & $\begin{array}{l}\text { Generally, our company's top managers have the } \\
\text { tendency to lead the competition with new idea or } \\
\text { product }\end{array}$ & 0.721 & & & \\
\hline & & EO44 & $\begin{array}{c}\text { Our company reacts quickly on the market } \\
\text { demand }\end{array}$ & 0.743 & & & \\
\hline & \multirow{2}{*}{$\begin{array}{c}\text { Competitive } \\
\text { Aggressiveness }\end{array}$} & EO51 & Our company is very aggressive & 0.756 & & & \\
\hline & & EO52 & Our company is very competitive & 0.723 & & & \\
\hline FP & Employee & FP12 & $\begin{array}{l}\text { Our company has good planning towards the } \\
\text { future of employees }\end{array}$ & 0.706 & 0.865 & 0.899 & 0.597 \\
\hline
\end{tabular}




\begin{tabular}{|c|c|c|c|c|c|c|c|}
\hline & Product & FP22 & $\begin{array}{l}\text { Our company's automation is higher than our } \\
\text { competitors in the same industry }\end{array}$ & 0.830 & & & \\
\hline & \multirow{2}{*}{ Development } & FP31 & $\begin{array}{c}\text { Our company is very keen on investing in new } \\
\text { market development }\end{array}$ & 0.733 & & & \\
\hline & & FP32 & $\begin{array}{l}\text { Our company is very keen on investing in new } \\
\text { technology development }\end{array}$ & 0.778 & & & \\
\hline & Revenue & FP41 & $\begin{array}{l}\text { Our company's income is higher than our } \\
\text { competitors in the same industry }\end{array}$ & 0.779 & & & \\
\hline & ROI & FP51 & $\begin{array}{l}\text { Our company's Return on Investment is higher } \\
\text { than our competitors in the same industry }\end{array}$ & 0.803 & & & \\
\hline \multirow{11}{*}{$\mathrm{KC}$} & \multirow[t]{2}{*}{ Socialization } & KC11 & $\begin{array}{c}\text { Our company emphasizes on the creation of } \\
\text { working environment that helps employees learn } \\
\text { skills }\end{array}$ & 0.700 & \multirow{11}{*}{0.930} & \multirow{11}{*}{0.939} & \multirow{11}{*}{0.586} \\
\hline & & $\mathrm{KC} 12$ & $\begin{array}{l}\text { Our company arranges employee meetings to } \\
\text { share and trade knowledge and experiences }\end{array}$ & 0.742 & & & \\
\hline & \multirow{3}{*}{ Externalization } & $\mathrm{KC} 21$ & Our company uses collaborative learning tools & 0.741 & & & \\
\hline & & KC22 & $\begin{array}{l}\text { Our company usually develops working group } \\
\text { discussion by using several techniques through } \\
\text { internet }\end{array}$ & 0.775 & & & \\
\hline & & KC23 & $\begin{array}{l}\text { Our company usually share information, } \\
\text { experiences, best practice, and learning to solve } \\
\text { problems }\end{array}$ & 0.732 & & & \\
\hline & & KC31 & $\begin{array}{l}\text { Our company emphasizes on manual and } \\
\text { document creation on products and services }\end{array}$ & 0.835 & & & \\
\hline & Combination & KC32 & $\begin{array}{c}\text { Our company emphasizes content creation from } \\
\text { management data gathering }\end{array}$ & 0.791 & & & \\
\hline & & KC33 & $\begin{array}{l}\text { Our company emphasizes content creation from } \\
\text { technical information gathering }\end{array}$ & 0.872 & & & \\
\hline & & KC41 & $\begin{array}{l}\text { Our company emphasizes on value seeking and } \\
\text { sharing }\end{array}$ & 0.764 & & & \\
\hline & Internalization & KC42 & $\begin{array}{c}\text { Our company emphasizes on new thoughts } \\
\text { seeking and sharing }\end{array}$ & 0.709 & & & \\
\hline & & KC43 & $\begin{array}{l}\text { Our company usually use on the job training to } \\
\text { enrich knowledge }\end{array}$ & 0.744 & & & \\
\hline
\end{tabular}

Based on the result of Fornell-Lacker criterion, discriminant validity, all three variables are valid. Correlation between items and the square root of AVE shown no problem with the top numbers being the biggest one. Table 4 shows the details of discriminant validity.

Table 4: Fornell-Lacker Criterion

\begin{tabular}{|l|l|l|l|}
\hline & EO & FP & KC \\
\hline EO & $\mathbf{0 . 7 5 4}$ & & \\
\hline FP & 0.752 & $\mathbf{0 . 7 7 3}$ & \\
\hline KC & 0.689 & 0.570 & $\mathbf{0 . 7 6 6}$ \\
\hline
\end{tabular}

The last part of discriminant validity measure beside loading factor and Fornell-Lacker criterion is Heterotrait-Monotrait Ratio (HTMT). The score for HTMT ratio should be $<1.00$ [31]. Based on the result, all variables are valid. Table 5 shows the HTMT result.

Table 5: HTMT Ratio

\begin{tabular}{|l|l|l|l|}
\hline & EO & FP & KC \\
\hline EO & & & \\
\hline FP & 0.848 & & \\
\hline KC & 0.703 & 0.616 & \\
\hline
\end{tabular}

$\mathrm{R}$ Square shows the proportion of variation of dependent variables towards independent variables. Results showed that $57,1 \%$ of firm performance could be described through entrepreneurial orientation and knowledge creation, while $47.5 \%$ of entrepreneurial orientation can be described through knowledge creation. R square result can be seen in table 6 .

Table 6: R Square

\begin{tabular}{|l|l|l|}
\hline & R Square & R Square Adjusted \\
\hline EO & 0.475 & 0.465 \\
\hline FP & 0.571 & 0.554 \\
\hline
\end{tabular}

Goodness of fit can be seen from the value of Standardized Root Mean Square Residual (SRMR) and Normal Fit Index (NFI). On this study, the result of SRMR estimated model is 0.108 while the NFI score is 0.555 . Although there are several PLS-SEM based model fit measures, but those measures are still in development [31].

After testing the validity and reliability, the next step was to test the path between variables. The test was done using SmartPLS. How the research model looked with the path coefficient and t-value can be seen in Figure 2. 


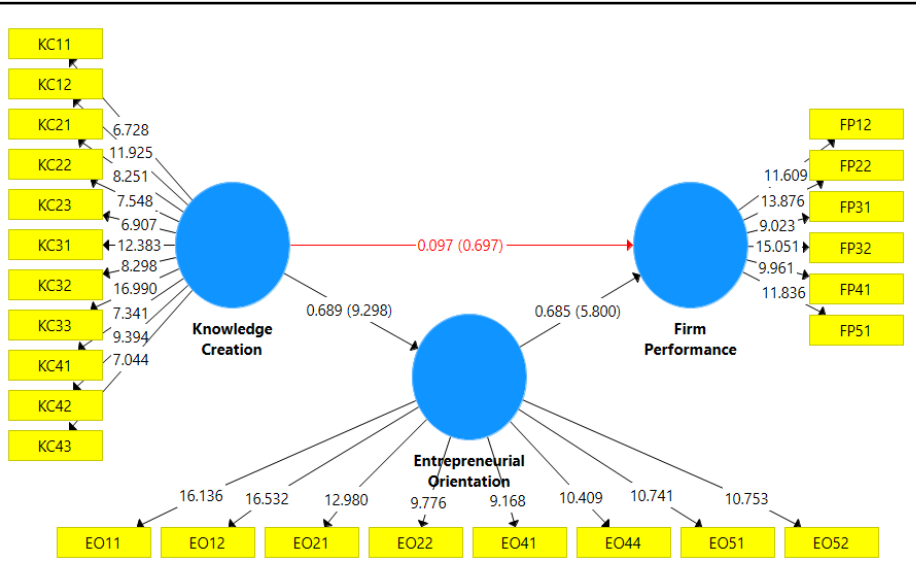

Figure 2: Research Model with Path Coefficient and T-Value

T-value should be $>2.021$ and $p$-value $<0.050$ for a significant path on a $5 \%$ error rate [33]. From the result, the direct effect of entrepreneurial orientation is positive and significant towards firm performance, and the direct effect of knowledge creation is positive and significant towards entrepreneurial orientation. However, knowledge creation has an insignificant direct effect on firm performance. By measuring the indirect effect, knowledge creation has a positive and significant effect on firm performance mediated by entrepreneurial orientation. Details on the structural equation model (SEM) test result can be seen in table 7.

Table 7: SEM Test Result

\begin{tabular}{|l|l|l|l|l|}
\hline & $\begin{array}{l}\text { Path } \\
\text { Coef. }\end{array}$ & T-Stat & P-Value & Sig. \\
\hline KC-> FP & 0.097 & $0.697^{*}$ & $0.486^{*}$ & Insignificant \\
\hline EO -> FP & 0.685 & 5.800 & 0.000 & $\begin{array}{l}\text { Positive \& } \\
\text { Significant }\end{array}$ \\
\hline KC->EO & 0.689 & 9.298 & 0.000 & $\begin{array}{l}\text { Positive \& } \\
\text { Significant \& }\end{array}$ \\
\hline KC->EO->FP & 0.472 & 4.873 & 0.000 & $\begin{array}{l}\text { Positive \& } \\
\text { Significant }\end{array}$ \\
\hline
\end{tabular}

\subsection{Discussion}

Based on this study, knowledge creation does not have a significant effect on firm performance. This argument supported previous research [34]. IT companies should not only be focusing on knowledge creation if they want to raise their performance. They should also think about other factors to make the knowledge creation effective. Therefore, hypothesis 1 is rejected.

Entrepreneurial orientation in this study is proved to have a positive and significant effect on firm performance. This statement strengthened the arguments done by previous researches $[21,35,36]$. By focusing on entrepreneurship, IT companies can find and exploit opportunities to improve their performance. Therefore, hypothesis 2 is accepted.

Knowledge creation has a positive and significant effect on entrepreneurial orientation, according to this study. This result strengthened previous research that argued the correlation between knowledge creation and entrepreneurial orientation [37] and supported the argument that showed knowledge creation affected entrepreneurial orientation [7]. IT companies must pay attention to knowledge creation to increase their entrepreneurial orientation. Therefore, hypothesis 3 is accepted.

This study showed that knowledge creation has a positive and significant effect on firm performance when it is mediated by entrepreneurial orientation. This result supported the previous research on the same topic [29]. Both knowledge creation and entrepreneurial orientation are essential factors to improve IT company performance. Therefore, hypothesis 4 is accepted.

\subsection{Implication}

IT companies generally rely on intangible resources such as knowledge as their important asset. Nevertheless, the result of this study showed that knowledge alone is not enough to make the company perform better. Therefore, medium-large IT companies in Jakarta should think about other factors while focusing on their knowledge creation.

Technology changes rapidly. IT companies should think about a way to face this challenge. Entrepreneurial orientation can help the companies to seek opportunities and adapt to changes. The result of this study showed that it is important to develop entrepreneurial orientation in the companies to increase their firm performance.

Another important result from this study is the relation between knowledge creation and entrepreneurial orientation. This study showed that knowledge creation is important to develop entrepreneurial orientation, which in the end raise the firm performance. Therefore, IT companies should develop both their knowledge creation and entrepreneurial orientation.

\section{Conclusion}

\subsection{Conclusion}

The results of this study indicate the factors that can increase IT firm performance. This study's main conclusion is that knowledge creation and entrepreneurial orientation are essential antecedents of firm performance, especially for companies in the IT sector. However, knowledge creation alone is not enough to raise firm performance. It must also be mediated by entrepreneurial orientation.

The interesting finding in this study is that entrepreneurial orientation mediates the relationship between knowledge creation and firm performance. It indicates that IT companies should create an environment that supports knowledge creation for the employees. Companies should also have entrepreneurial orientation to adapt with the fast-changing environment.

\subsection{Limitation and Future Work}

This study has several limitations. The analysis in this study was done by quantitative approach. Adding qualitative approaches by having interview or focus group discussion on future research will enrich this study. Mixed-method research is also a good approach to understand more about the industry.

The companies observed is also limited to medium-large IT companies. Future research can be done to small IT companies. The knowledge creation might be different in small companies and their way to face the changes can also be different. Therefore, 
doing study in small IT companies or conducting comparative study between small, medium, and large IT companies will enrich this study.

Other limitation is the scope of this research. This study used IT companies in Jakarta, Indonesia. Therefore, it will be hard to generalize this result to other countries. Future research ought to be held on other countries as well.

\section{References}

[1] C.M. Christensen, The Innovator's Dilemma: When New Technologies Cause Great Firms to Fail, Harvard Business School Press, Boston, Massachussets, USA, 1997.

[2] J.R.L. Kaivo-oja, I.T. Lauraeus, "The VUCA approach as a solution concept to corporate foresight challenges and global technological disruption," Foresight, 20(1), 27-49, 2018, doi:10.1108/FS-06-2017-0022.

[3] K. Das, M. Gryseels, P. Sudhir, K.T. Tan, Unlocking Indonesia's Digital Opportunity, 2016.

[4] D.J. Teece, G. Pisano, A. Shuen, "Dynamic Capabilities and Strategic Management," Strategic Management Journal, 18(7), 509-533, 1997.

[5] S. Venkataraman, "The Distinctive Domain of Entrepreneurship Research," Advances in Entrepreneurship, Firm Emergence and Growth, 3, 119-138, 1997.

[6] G. Lumpkin, G.G. Dess, "Linking two dimensions of entrepreneurial orientation to firm performance," Journal of Business Venturing, 16(5), 429451, 2001, doi:10.1016/S0883-9026(00)00048-3.

[7] C. Weerakoon, A.J. McMurray, N. Rametse, P. Arenius, "Knowledge creation theory of entrepreneurial orientation in social enterprises," Journal of Small Business Management, 58(4), 834-870, 2020, doi:10.1080/00472778.2019.1672709.

[8] N.A. Omar, K. Professional, M.A. Nazri, "The Effect of Entrepreneurial Orientation, Innovation Capability and Knowledge Creation on Firm Performance: A Perspective on Small Scale Entrepreneurs," Jurnal Pengurusan, 48, 187-200, 2016.

[9] M.S. Aliyu, H.B. Rogo, R. Mahmood, "Knowledge Management , Entrepreneurial Orientation and Firm Performance: The Role of Organizational Culture Knowledge Management , Entrepreneurial Orientation and Firm Performance: The Role of Organizational Culture," Asian Social Science, 11(23), 2015, doi:10.5539/ass.v11n23p140.

[10] B. Liu, J. Wang, "Demon or angel: an exploration of gamification in management," Nankai Business Review International, 11(3), 317-343, 2020, doi:10.1108/NBRI-02-2018-0013.

[11] J.B. Santos, L.A.L. Brito, "Toward a subjective measurement model for firm performance," BAR - Brazilian Administration Review, 9(SPL. ISS), 95117, 2012, doi:10.1590/S1807-76922012000500007.

[12] K. Cameron, "A STUDY OF ORGANIZATIONAL EFFECTIVENESS AND ITS PREDICTORS,” Management Science, 32(I), 87-112, 1986.

[13] T. Connolly, E.J. Conlon, S.J. Deutsch, "Organizational Effectiveness: A Multiple-Constituency Approach.," Academy of Management Review, 5(2), 211-218, 1980, doi:10.5465/amr.1980.4288727.

[14] R.L. Daft, Management, 10th ed., Cengage Learning, Ohio, 2012.

[15] S.M. Tseng, P.S. Lee, "The effect of knowledge management capability and dynamic capability on organizational performance," Journal of Enterprise Information Management, 27(2), 158-179, 2014, doi:10.1108/JEIM-052012-0025.

[16] P.C. Izunwanne, "Developing an Understanding of Organisational Knowledge Creation: A Review Framework," Journal of Information \& Knowledge Management, 16(2), 2017, doi:10.1142/S0219649217500204.

[17] M. Tsai, Y. Li, "Knowledge creation process in new venture strategy and performance," 60(1), 371-381, 2007, doi:10.1016/j.jbusres.2006.10.003.

[18] I. Nonaka, "A Dynamic Theory of Organizational Knowledge Creation," Organization Science, 5(1), 14-37, 1994, doi:10.1287/orsc.5.1.14.

[19] D. Hidayat, E. Abdurachman, Elidjen, Y. Hutagaol, "Empirical Studies on Knowledge Creation and Performance: a Literature Review," in 2020 International Conference on Information Management and Technology (ICIMTech) 533, Bandung, Indonesia: 533-537, 2020.

[20] C. Curado, "The Knowledge Based-View of the Firm: From Theoretical Origins To Future Implications," Igarss 2014, (1), 1-5, 2006, doi:10.1007/s13398-014-0173-7.2.

[21] H. Montiel-Campos, "Entrepreneurial orientation and market orientation: Systematic literature review and future research," Journal of Research in Marketing and Entrepreneurship, JRME-09-2017-0040, 2018,
doi:10.1108/JRME-09-2017-0040.

[22] M. Madhoushi, A. Sadati, H. Delavari, M. Mehdivand, R. Mihandost, "Entrepreneurial Orientation and Innovation Performance: The Mediating Role of Knowledge Management," Asian Journal of Business Management, 3(4), 310-316, 2011.

[23] S. Shane, S. Venkataraman, "The Promise of Entrepreneurship as a Field of Research," The Academy of Management Review, 25(1), 217, 2000, doi: $10.2307 / 259271$

[24] D. Miller, "The Correlates of Entrepreneurship in Three Types of Firms," Management Science, 29(7), 770-791, 1983, doi:10.1287/mnsc.29.7.770.

[25] P. Heisig, O.A. Suraj, A. Kianto, C. Kemboi, G. Perez Arrau, N. Fathi Easa, "Knowledge management and business performance: global experts' views on future research needs," Journal of Knowledge Management, 20(6), 1169 1198, 2016, doi:10.1108/JKM-12-2015-0521.

[26] F. Zouaghi, M. Sánchez, M.G. Martínez, "Did the global financial crisis impact firms' innovation performance? The role of internal and external knowledge capabilities in high and low tech industries," Technological Forecasting and Social Change, 132(April 2016), 92-104, 2018, doi:10.1016/j.techfore.2018.01.011.

[27] R. Basco, F. Hernández-Perlines, M. Rodríguez-García, "The effect of entrepreneurial orientation on firm performance: A multigroup analysis comparing China, Mexico, and Spain," Journal of Business Research, 113(May), 409-421, 2020, doi:10.1016/j.jbusres.2019.09.020.

[28] Y. Liu, M. Wang, "Entrepreneurial orientation, new product development and firm performance: the moderating role of legitimacy in Chinese hightech SMEs," European Journal of Innovation Management, 2020, doi:10.1108/EJIM-05-2020-0204.

[29] R. Zacca, M. Dayan, T. Ahrens, "Impact of network capability on small business performance," Management Decision, 53(1), 2-23, 2015, doi:10.1108/MD-11-2013-0587.

[30] Badan Pusat Statistik, Sensus Ekonomi 2016 Direktori Usaha/Perusahaan Menengah Besar Kategori Informasi dan Komunikasi, 2017.

[31] J. Hair Jr, G.T. Hult, C. Ringle, M. Sarstedt, A Primer on Partial Least Squares Structural Equation Modeling (PLS-SEM), 2017.

[32] S. Sachdev, H. Verma, "Relative importance of service quality dimensions: a multisectoral study," Journal of Services Research, 4(1), 93, 2004

[33] U. Sekaran, R. Bougie, Research Methods for Business, 7th Editio, Wiley, West Sussex, UK, 2016, doi:10.1007/978-94-007-0753-5_102084.

[34] C.E. Lucier, J.D. Torsilieri, "Why knowledge programs fail: A CEO's guide to managing learning," Strategy \& Business, 9(4), 14-28, 1997.

[35] M.I. Hanif, F. Malik, A.B. Abdul Hamid, A.B.A. Hamid, "The effect of knowledge management and entrepreneurial orientation on organization performance," Journal of Entrepreneurship Education, 21(4), 2651, 2018.

[36] R. Masa'deh, J. Al-Henzab, A. Tarhini, B.Y. Obeidat, "The associations among market orientation, technology orientation, entrepreneurial orientation and organizational performance," Benchmarking, 25(8), 3117 3142, 2018, doi:10.1108/BIJ-02-2017-0024.

[37] F. Vidic, "Entrepreneurial Orientation (EO) and Knowledge Creation (KC)," International Journal of Economic Sciences and Applied Research, 6(2), 103-124, 2013. 